\title{
Phosphatidylinositol-Glycan Biosynthesis Class F Protein
}

National Cancer Institute

\section{Source}

National Cancer Institute. Phosphatidylinositol-Glycan Biosynthesis Class F Protein. NCI Thesaurus. Code C104794.

Phosphatidylinositol-glycan biosynthesis class F protein (219 aa, $25 \mathrm{kDa}$ ) is encoded by the human PIGF gene. This protein plays a role in glycophosphatidyl inositol anchor biosynthesis. 